\title{
In-Situ and Ex-Situ Phycoremediation Competence of Innate Scenedesmus Sp. On Polluted River Water
}

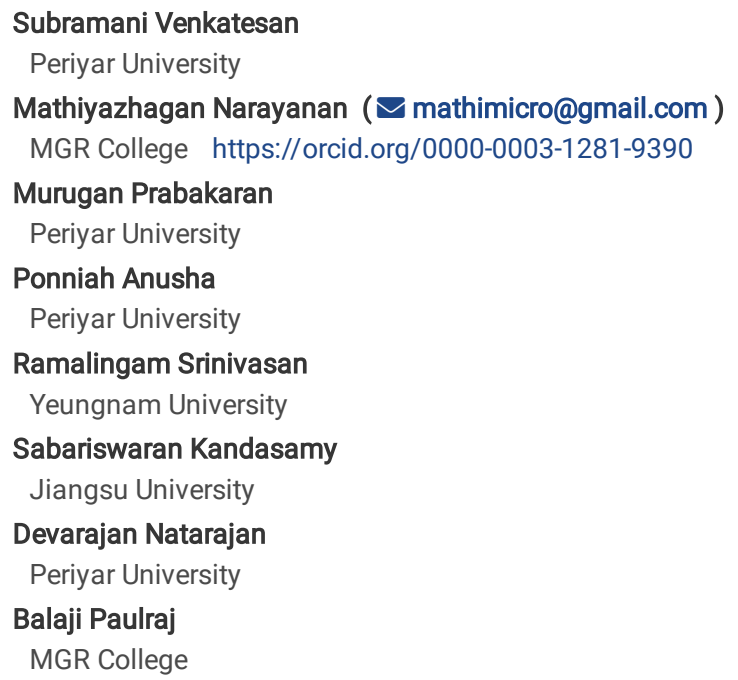




\section{Abstract}

The present study was aimed to investigate the ex-situ and in-situ phycoremediation efficacy of native Scenedesmus sp. in polluted Thirumanimuthar River water sample. Based on the macroscopic and microscopic analysis the predominant microalgae culture from polluted water was identified as Scenedesmus sp. Most of the physicochemical parameters (EC: 3110.00 micro mho cm${ }^{-1}$, turbidity: $17.10 \mathrm{mg} \mathrm{L}^{-1}$, total hardness: $812.00 \mathrm{mg} \mathrm{L}^{-1}$, BOD: $230 \mathrm{mg} \mathrm{L}^{-1}$, and COD: $352 \mathrm{mg} \mathrm{L}^{-1}$ ) and some minerals such as Ca: $232.00 \mathrm{mg} \mathrm{L}^{-1}$ and Sulfate: $532.00 \mathrm{mg} \mathrm{L}^{-1}$ were crossing the permissible limits. Among three sets of treatments (I, II, \& III), $3 \%$ in ex-situ (treatment III), and $30 \%$ in in-situ (treatment III) were shown a better reduction in physicochemical properties of polluted river water in 14 days of treatment. The in-situ study has shown better pollutants reduction than ex-situ as it reduced BOD \& COD 27.83\% and 23.30\%, respectively. Further, the chloride, sulphate, phosphate, sodium, calcium, and magnesium were reasonably reduced up to $40.00,43.61,31.03,18.75,70.26$, and $33.93 \%$, respectively. The FTIR analysis confirmed that the presence of pollutants absorbing functional groups in dried biomass of Scenedesmus sp. and the SEM analysis image confirmed the absorption of pollutants by resulting in morphology changes of Scenedesmus sp. The results concluded that a significant reduction was found in most tested physicochemical and minerals contents in the treated water through the in-situ study than the ex-situ approach. Through this sustainable phycoremediation strategy, the pollutant reducing Scenedesmus sp. could be used as feedstock for biofuel production.

\section{Introduction}

Globally, most of the rivers and freshwater streams are primarily polluted by industrial wastes which are derive from different industries such as petrochemicals, fertilizers, oil refineries, paper, textiles, sugar mills, steel, tanneries, distilleries, and pharmaceuticals, etc. (Liu et al. 2019; Leng et al. 2020). The untreated effluents released from textile industries contain different kinds of chemicals (acids, minerals, alkalis, and several dyes) that cause severe water pollution (Sarayu and Sandhya 2012). The more population-holding nations from Asian continents, the water pollution became a thoughtful issue since more population eruption leads to the discharge of more volume of untreated municipal wastewater to existing water reservoirs and create water pollution (Angelaalincy et al. 2017). Besides, in India, all types of pollutions were collectively accountable for $21 \%$ of demises from cerebrovascular disease, $26 \%$ of demises due to coronary artery disease, $23 \%$ by hemorrhagic stroke, $51 \%$ to respiratory infections, and $43 \%$ due to lung carcinoma. In developing countries, environmental pollution has been accountable for numerous demises as AIDS and tuberculosis collectively made (NGT 2019). Among the various pollution, water pollution is one of the significant causes of illness to humans and animals (Leng et al. 2020).

The rapid urbanization leads to releasing a huge volume of untreated sewage into the river water. According to the national green tribunal principal bench, New Delhi, India (NGT 2019), the untreated effluent releasing is the solitary cause of pollution of surface and groundwater. Further, about $60 \%$ of untreated urban sewage of India is directly disposed into the river and reduce the quality of water and made it unfit for human utilization (consumption) and cause diseases, demises, and critical destruction to water, earth, and air (Murty 2011; Asselborn et al. 2015). The Central Pollution Control Board (CPCB) of India, performed a regular portfolio of water resource, polluted water creation, and it reported that the disposal of around 33,000 million liters of polluted water created every day from Class-I and Class - II municipalities (CPCB Report 2009). These unprocessed discharges from houses pollute the surface and groundwater resources.

The modern industrialization process and inappropriate discharge of residues contained effluents into water bodies caused heavy metal pollution in the surrounding environment and produced serious issues (Verma et al. 2020). Hence, finding the most suitable eco-friendly technologies with potential pollutants removing or minimizing agents is significant now. Traditional methods such as physical (filtration, sedimentation, etc.), chemical (flocculation, precipitation, etc.), and biological (phytoremediation, bioremediation, etc.) treatment are reducing due to economic crisis, treatment time duration, and limitations in using a large scale (Li et al. 2013). The phycoremediation is an alternative, eco-friendly, efficient, and low cost (Gonçalves et al. 2017; Li et al. 2013) technique to treat polluted water. Since microalgae are one of the crucial parts of the polluted microbial niche, which act as a significant contributor in polluted water selfpurification (Gonçalveset al. 2017) and also used for the elimination of pollutants such as excess nutrients, xenobiotics, and $\mathrm{CO}_{2}$ which is low cost-effective, non-intrusive and safer technology (Ajayan et al. 2015). Historically, microalgae have been employed to treat domestic polluted water through raceway ponds and photo-bioreactors. Besides that, they possess the efficiency to uptake heavy minerals from polluted water and serve as a significant role in heavy metal removal (Kumar et al. 2015). For the past few decades, the two common algal species like Chlorella and Scenedesmus sp. are majorly used to treat polluted water (Krohn-Molt et al. 2017).

Recently, many countries, namely, Australia, the USA, Thailand, Taiwan, and Mexico, developed algal and fungal technology to remediate polluted waters in the environment (Liu et al. 2013). The domestic sewage water in a warmer climate is the ideal habitats for the growth of Scenedesmus sp. and Chlorella sp. (Tripathi et al. 2019). The various species of microalgae viz, Chlorella sp., Scenedesmus sp., Phormidium sp., Botryococcus sp., Chlamydomonas sp., and Spirulina sp. have been utilized for treating domestic polluted water (Wang et al. 2015; Gonçalves et al. 2017; Liu et al. 2019). As per the recent National Green Tribunal report (2019), the physicochemical properties of Thirumanimuthar River were not meeting the India standards. With this brief background, the current study was focused on in-situ and ex-situ phycoremediation of contaminated water collected from highly polluted region of the "Thirumanimuthar" river (Salem, Tamil Nadu, India) using native microalgae species.

\section{Materials And Methods}

\subsection{Brief profile about the study area}

The study area Thirumanimuthar River located at the Poolavari village belongs to Salem District, Tamil Nadu, India ( $11^{\circ} 36^{\prime} 40.8^{\prime \prime} \mathrm{N}$ latitudes, and $78^{\circ} 06^{\prime} 16.9^{\prime \prime} \mathrm{E}$ longitudes, Fig. 1). This area received an average annual rainfall was $800 \mathrm{~mm}$. The geography of the study area revealed that the presence of archaean crystalline rocks and surrounded by several hillocks in all directions, namely, Shevaroys and Nagaramalai (North), Jarugumalai Hills (South), Kanjamalai (West), and Goudamalai (East). This river has been polluted by releasing untreated dyeing and bleaching (155 unauthorized dyeing and bleaching units and 125 illegal manual dyeing units) industrial effluents, municipal and medical wastes from in and around the Salem district of Tamilnadu. Further, it polluted the 
surface and groundwater and made them unfit for drinking and irrigation (NGT 2019). The farmers depend entirely on this river for agriculture activities and drinking purposes due to insufficient annual rainfall.

\subsection{Collection of polluted water}

The polluted water sample was collected from Thirumanimutharu River, at Poolavari village, Salem district of Tamil Nadu. The samples were collected in sterile polyethylene bottles that added a few drops of $\mathrm{HNO}_{3}$ to prevent loss of elements and transported to the laboratory for further investigation (Ajayan et al. 2015).

\subsection{Isolation, culturing, and identification of microalgae}

Initially, $25 \mu \mathrm{m}$ diameter sized phytoplankton net was used to filter the dust from the polluted river water. Later, 0.45 size Whatman No. 1 filleter paper was used to filter the microalgae species from polluted water and immediately observed under a standard microscope and confirmed the presence of microalgae in filter paper. The filter paper was rinsed with sterile distilled water and $1 \mathrm{~mL}$ of microalgae suspended rinsed water was inoculated in petri plates containing 25 $\mathrm{mL}$ of semi-solid Bold's Basal Medium (BBM) with $200 \mu \mathrm{g} \mathrm{mL}^{-1}$ of ampicillin (to avoid bacterial growth) and incubated for 3 weeks at $28 \pm 1{ }^{\circ} \mathrm{C}$ with day/night cycling illumination ( $40 \mu \mathrm{mol}$ photons $\mathrm{m}^{-2} \mathrm{~s}^{-1} ; 15 \mathrm{~h}$ light/ $9 \mathrm{~h}$ dark). The growth of green color colonies has appeared in the $2^{\text {nd }}$ and $3^{\text {rd }}$ weeks of the incubation period, and those algae were identified as Scenedesmus sp. (through the study of macroscopically and microscopically: using a compound binocular microscope) that transferred into a sterilized BBM containing new petri dish. A single colony of Scenedesmus sp. was isolated and inoculated in liquid BBM media. The growth of algae (after two weeks of incubation) was measured using a UV-visible spectrophotometer at $680 \mathrm{~nm}$ (Mehrabadi et al. 2015 ).

\subsection{Ex-situ experimental setup for phycoremediation}

The Scenedesmus sp. culture was spun at $7000 \mathrm{rpm}$ for $12 \mathrm{~min}$ and obtained pellet (biomass) was rinsed with sterile distilled water, and seed inoculum was prepared with three different density $\left(5 \times 10^{4}\right.$ cells mL ${ }^{-1}, 7.5 \times 10^{4}$ cells mL ${ }^{-1}$, and $10 \times 10^{4}$ cells $\left.\mathrm{mL}^{-1}\right)$ using spectrophotometer $(680 \mathrm{~nm})$ and a hemocytometer. These three different cell densities $\left(5-10 \times 10^{4}\right.$ cells $\left.\mathrm{mL}^{-1}\right)$ of Scenedesmus sp. were chosen for ex-situ phycoremediation experiment study as per the methodology of Tripathi et al. (2019) as follows in triplicates in a glass container.

Treatment I: $5 \times 10^{4}$ cells $\mathrm{mL}^{-1}$ of Scenedesmus sp. in $3 \mathrm{~L}$ of polluted river water sample supplemented with $200 \mu \mathrm{g} \mathrm{mL} \mathrm{L}^{-1}$ of ampicillin (to assure the pollutant reduction efficiency by test microalgae species)

Treatment II: $7.5 \times 10^{4}$ cells $\mathrm{mL}^{-1}$ of Scenedesmus sp. in $3 \mathrm{~L}$ of polluted river water sample supplemented with $200 \mu \mathrm{g} \mathrm{mL}{ }^{-1}$ of ampicillin

Treatment III: $10 \times 10^{4}$ cells $\mathrm{mL}^{-1}$ of Scenedesmus sp. in $3 \mathrm{~L}$ of polluted river water sample supplemented with $200 \mu \mathrm{g} \mathrm{mL}{ }^{-1}$ of ampicillin

Control : $3 \mathrm{~L}$ of polluted river water sample supplemented with $200 \mu \mathrm{g} \mathrm{mL}^{-1}$ of ampicillin without seed inoculum.

The treatment setups were incubated at $28 \pm 1^{\circ} \mathrm{C}$ for 14 days under sterile laboratory conditions. Illumination was provided to cultures using casual white luminous lamps at 4000 Lux with a dark/light period of $16: 8 \mathrm{~h}$ with periodical manual shaking (Verma et al. 2020).

\subsection{In-situ phycoremediation of polluted water}

In-situ phycoremediation study was performed near the bank of the Thirumanimutharu River at Poolavari village, Salem District, Tamil Nadu by setting up a waste stabilization pond system ( $5.75 \times 2 \times 2 \mathrm{~m}$ in size), and the treatment of polluted water was conducted for 14 days with (periodical manual blending) following experimental setups

Treatment I: $5 \times 10^{4}$ cells $\mathrm{mL}^{-1}$ of Scenedesmus sp. in $100 \mathrm{~L}$ of polluted river water sample supplemented with $200 \mu \mathrm{g} \mathrm{mL}{ }^{-1}$ of ampicillin

Treatment II: $7.5 \times 10^{4}$ cells $\mathrm{mL}^{-1}$ of Scenedesmus sp. in $100 \mathrm{~L}$ of polluted river water sample supplemented with $200 \mu \mathrm{g} \mathrm{mL}{ }^{-1}$ of ampicillin

Treatment III: $10 \times 10^{4}$ cells $\mathrm{mL}^{-1}$ of Scenedesmus sp. in $100 \mathrm{~L}$ of polluted river water sample supplemented with $200 \mu \mathrm{g} \mathrm{mL}{ }^{-1}$ of ampicillin

Control : $100 \mathrm{~L}$ of polluted river water sample supplemented with $200 \mu \mathrm{g} \mathrm{mL}{ }^{-1}$ of ampicillin without culture

Triplicate setup was performed, and at the end of the $14^{\text {th }}$ day, both the treated and control polluted river water sample was collected from the respective ponds and analyses the physicochemical properties of them and calculated the percentage of phycoremediation occurred by Scenedesmus sp. (Sutherland and Ralph 2019). Before the sample was taken, the suspected amount of water evaporated during the treatment process was filled with elements free sterile distilled water.

\subsection{Growth kinetics of Scenedesmus sp. during in-situ and ex-situ phycoremediation process}

During the in-situ and ex-situ treatment, the $\mathrm{pH}$ of water and growth rate (density: number of cells $\mathrm{mL}^{-1}$ ) of Scenedesmus sp. were measured at $48 \mathrm{~h}$ intervals up to 14 days of treatment (Derakhshandeh and Tezcan Un 2019), using a pH meter, hemocytometer, and spectrophotometer (at $680 \mathrm{~nm}$ ). Later, the biomass of Scenedesmus sp. from the treated (in-situ and ex-situ) water samples were harvested and dried in an oven for further analyses like FTIR and SEM.

\subsection{Analysis of physicochemical properties of pre and post-treated river water sample}


The various physicochemical characteristics of pre and post-treatment of in-situ and ex-situ polluted water were carried out in terms of odor, turbidity, electrical conductivity, $\mathrm{pH}$, total dissolved solids ( $\mathrm{mg} \mathrm{L}^{-1}$ ), total alkalinity, total hardness, Biological Oxygen Demand (BOD), Chemical Oxygen Demand (COD), Dissolved Oxygen (DO), free ammonia, and nitrite along with the quantification of minerals (calcium, magnesium, sodium, iron, chloride, sulfate, and phosphate according to the standard protocols developed by American Public Health Association (APHA 2005) using Inductively Coupled Plasma-Optical Emission Spectrometry (ICP-OES Agilent 5900 SVDV). All the analyses were carried out at District Water Testing Laboratory (TWAD), Govt. of Tamil Nadu, Salem District, Tamil Nadu, India.

\subsection{Fourier Transforms Infrared Spectroscopy (FTIR) and Scanning Electron Microscope (SEM) analysis}

The dry Scenedesmus sp. biomass was subjected to the FTIR spectroscopy and SEM analysis. The Infrared spectra were documented in the range of 4000 $\mathrm{cm}^{-1}$ to $400 \mathrm{~cm}^{-1}$ using an IR spectroscopy (IR-200, Nicolet, Thermo Fisher). The morphology of algae (0.71 to $1.0 \mathrm{~mm}$ in size dried) was observed under the Scanning Electron Microscope (SEM, JSM-5400, JEOL) (Ajayan et al. 2015). The FTIR and SEM analyses of the samples were performed at Central Instrumentation Facility, St. Joseph's College (Autonomous), Tiruchirappalli, Tamil Nadu, India.

\section{Results And Discussion}

\subsection{Isolation and characterization of microalgae}

The pure culture of microalgae grown in BBM was enumerated genomic identification by macroscopic and microscopic observations. Under the macroscopic observation, each colony morphological appearance seemed as massive with the flourishing growth in nature on BBM containing plates (Fig. 2a). Since it contains an enormous quantity of plastids filled with chlorophylls, it showed flourishing green color colonies (Derakhshandeh and Tezcan 2019), which support the photosynthesis and support active metabolisms of overloaded pollutants in water (Wan et al. 2016). Besides, that under the binocular microscopic observation, the cells appear as spherical to ellipsoidal in shape and single-celled or colonial forming 2 to 32 celled, usually 4 or 8 celled coenobia or colonies and arranged in either linear or alternating or in 2-3 rows and connecting with the adjacent walls (Fig. 2b). Similarly, Gour et al. (2016) reported that the Scenedesmus quadricauda and Scenedesmus dimorphus developed distinctive colonies comprising 4 or 8 cells while two cell formation and they noted the Scenedesmus sp. with single cells arrangement.

Similarly, Wang et al. (2016) reported the microscopic view of the algal cells appeared as spherical to ellipsoidal, elongate, or fusiform, which supported the present study. The isolated colonies were characterized and identified as Scenedesmus sp. based on the morphology under the microscopic characteristics. Previously, some of the microalgae were isolated from polluted water and identified by using microscopic characteristics and the predominant species are belongs to Cyanobacteria, S. obliquus and C. vulgaris (Tang et al. 2018), Chlorella sp., Scenedesmus sp., and Neochloris sp. (Gonçalves et al. 2017) that strengthen the present findings.

\subsection{Growth rate of Scenedesmus sp.}

The algal growth in the ex-situ and in-situ based phycoremediation process with various concentration (Fig. 3a, b, c, \& d) of Scenedesmus sp. (Treatment I, II, \& III) culture on the treatment of polluted river water was measured and counted by a spectrophotometer and hemocytometer. Out of three, the treatment III results showed that algal growth was increased gradually in both ex-situ and in-situ conditions on the $6^{\text {th }}$ day onwards. Conversely, the algal growth in the labscale was lower than the in-situ trial. Further, significant pH changes (from 6.99 to 8.44 ) were observed in both ex-situ and in-situ study on the $12^{\text {th }}$ day of treatment

(Fig. 4a \& Fig. 5a) and it was statistically significant at $P<0.005$. The results showed that Scenedesmus sp. growth in polluted water continued up to the $14^{\text {th }}$ day of treatment from $6^{\text {th }}$ day onwards (Fig. $4 \mathrm{~b} \& 5 \mathrm{~b}$ ). Entirely, the Scenedesmus sp. growth was considerably higher in in-situ treatment than ex-situ study, and it was statistically significant at $P<0.005$. Since, in the in-situ study, high light intensity 25,000 lux in the morning, 75,000 lux in the noon, and 15,000 lux in the evening were recorded. The better aeration was observed in an entire day and, thus, might be a possible reason for the high growth of algae in in-situ than ex-situ study (Fig. 4b \& 5b) (Derakhshandeh and Tezcan Un 2019). Besides that, light intensity the cycles of light and dark period was also the most significant factor in the growth of Scenedesmus sp. (Xiong et al. 2016). Nonetheless, it was limited in ex-situ study. Several researchers reported growth conditions for various microalgae species in polluted water treatment which including N. oleoabundans, Chlorella (Anjos et al. 2013), Scenedesmus sp.A. microscopica, S. platenesis (Yu et al. 2019), Chlamydomonas sp. (Suresh Kumar et al. 2015).

\subsection{Physicochemical and metal analysis}

The pretreated physicochemical properties of polluted Thirumanimuthar River water sample results showed that specific parameters (EC: 3110.00 micro mho $\mathrm{cm}^{-1}$, turbidity: 17.10 , total hardness: 812.00 , BOD: 230 , and COD: $352 \mathrm{mg} \mathrm{L}^{-1}$ ) and some minerals (Ca: 232.00 , Sulfate: $532.00 \mathrm{mg} \mathrm{L}^{-1}$ ) were crossing the permissible limits of Indian standards like Central Pollution Control Board (CPCB), Indian Council of Medical Research (ICMR), and Indian Standards Institution (ISI) of India. Further, a considerable amount of phosphate, nitrite, ammonia, sodium, magnesium, and chloride was also present in the river water (Table 1). The excess quantity of nutrients such as $\mathrm{N}_{2}$ and $\mathrm{P}_{4}$ enriched effluents can create eutrophication in the freshwater system (Glibert et al. 2017). These excess nitrogen and phosphorus nutrient load in water could enhance the growth of several species of microalgae such as Chlorella sp., Scenedesmus sp., Neochloris sp., etc. Hence these native green microalgae have been used for several years as an alternative biological treatment to eliminate organic pollutants $\left(\mathrm{N}_{2}\right.$ and $\left.\mathrm{P}_{4}\right)$ from various polluted water (Zhao et al. 2015; Gonçalves et al. 2017).

The major source of these pollutants in this river water might be received from untreated effluents of dyeing, bleaching industries, and municipal effluents (Ajayan et al. 2015). From the past seven decades onwards, microalgae like Chlorella sp., Scenedesmus sp.,Dundiella sp., etc. have been commercially used as suitable agents for polluted water treatment. The physicochemical and metal analyses of three sets (Treatment I, II, \& III) of treated polluted water of both ex-

Page 4/14 
situ and in-situ methods were presented in Table 1. The treatment III of ex-situ and in-situ results show better phycoremediation than I and II. Initially, both the ex-situ and in-situ (stabilization pond system) remediation of the polluted water appeared as small black (Fig. 6a) in color with an odor which turned into green color and odorless at the end of treatment (Fig. 6b). The BOD and COD values in the in-situ study were found as 166 ( $\mathrm{mg} \mathrm{L}^{-1}$ ) and 270 (mg L $\mathrm{L}^{-1}$ ) while labscale $205\left(\mathrm{mg} \mathrm{L}^{-1}\right)$ and $310\left(\mathrm{mg} \mathrm{L}^{-1}\right)$, respectively. The BOD and COD level in the

in-situ study was reduced to $27.83 \%$ and $23.30 \%$, whereas in the lab-scale, $10.87 \%$ and $11.93 \%$ compared with the control respectively. Tang et al. (2018) noted a similar amount of BOD and COD reduction in the treated municipal sewage polluted water used $C$. vulgaris and $S$. obliquus. This might be high growth of microalgae and photosynthesis mechanism. Gupta and Rastogi (2008) explained microalgae role in polluted water treatment, which reduced the significant number of contaminants in various physicochemical parameters like COD, BOD, and turbidity. Biological oxygen demand is especially useful in evaluating the auto-purification capacity of streams, which serves as a measure to assess the quantity of polluted water, safely assimilated by a stream (Rahman and Hasegawa 2011). Similarly, Gonçalves et al. (2017) reported that the Dundiella sp. has the highest removal of BOD, COD, and ammonium from polluted water.

Significantly increased pH values (up to $8.44,14 \%$ - 20\%) were found in both ex-situ and in-situ phytoremediation processes (Fig. 4a, 5a, and 7 ). The present results were agreed with

Liu et al. (2019). They found that the effect of stirring on the high growth of algae and reported that the photosynthesis could induced higher pH values in ammonia polluted water during the phycoremediation by Scenedesmus obliquus. Norvill et al. (2016) found that ammonia may be exposed off into the air and resulted in an increased level of $\mathrm{pH}$ in algal cultures. The total dissolved solids (TDS) content of polluted river water in both ex-situ and in-situ studies was $32 \%$ decreased compared to the control that depends on utilizing various types of nutrients by the algae (Posadas et al. 2015). Glibert et al. (2017) demonstrated that the removal of $>50 \%$ of TDS in 9 days of polluted water treatment was carried out by the Chlorella minutissima, supporting the present findings. We obtained the efficient removal of ammonia (100\%) from polluted water by Scenedesmus sp. and it was supported by the outcome of Yang et al. (2016), who reported the efficient removal of ammonia in polluted water and utilized the harvested algae for biodiesel production. The obtained result was quite comparable to the findings of Wang et al. (2015), who reported the efficacy of $C$. vulgaris and $S$. dimorphus are similar to Phormidium bonheri in removing ammonia (95\%).

Scenedesmus sp., shown a remarkable effect on the electrical conductivity value of polluted water which has been reduced to $32 \%\left(2110 \mathrm{mho} \mathrm{cm}^{-1}\right)$ in both ex-situ and in-situ. The EC value of water is quite linear with thevolume of dissolved ions were reported by Mata et al. (2012). Mencio et al. (2016) stated that the increased total hardness level in water was unsuitable for agricultural purposes. The present study observed the total hardness of in-situ and ex-situ analysis were reduced to $316 \mathrm{mg} \mathrm{L}^{-1}(61.08 \%)$ and $328 \mathrm{mg} \mathrm{L}^{-1}(59.61 \%)$ from the control value $812 \mathrm{mg} \mathrm{L}^{-1}$ by Scenedesmus sp., due to the efficient uptake of the nutrients, respectively.

The ex-situ phycoremediation study by Scenedesmus sp. on minerals removal in polluted river water was analyzed. The result states that the treatment III has effectively performed the phycoremediation I and II. In the III treated water sample, the presence ( $\mathrm{mg} \mathrm{L}^{-1}$ ) of $252,300,2,260,69$, and 37 of chloride, sulphate, phosphate, sodium, calcium, and magnesium respectively were occurred and that was equivalent to $40.00 \%, 43.61 \%, 31.03 \%, 18.75 \%, 70.26 \%$, and $33.93 \%$ reduction (Fig. 7) while compared to those found in control as 420, 532, 2.90, 320, 232, and $56 \mathrm{mg} \mathrm{L}^{-1}$, respectively. Whereas, 248, 295, 1.5, 260, 67, and 36 mg $\mathrm{L}^{-1}$, of chloride, sulfate, phosphate, sodium, calcium, and magnesium, were found in the in-situ study (in-situ treatment III) that expressed more mineral reduction potential of Scenedesmus sp. than the ex-situ. An increased level of potassium $(33.33 \%-55.56 \%)$ was noted in the treated river water, and it might be derived from as an output of metabolic activity of Scenedesmus sp.

The amount of DO concentration was increased significantly from the control value 2.86 , and $3.80 \mathrm{mg} \mathrm{L}^{-1}$ in the ex-situ and in-situ study after the treatment (III) that corresponds to $73.33 \%$ and $130.30 \%$ surge, respectively. Since the microalgae in polluted water treatment provide oxygen during the phycoremediation process, it could enhance the native bacterial breakdown of organic pollutants and minimize their toxicity (Cheah et al. 2018). After treatment, $100 \%$ nitrate $\left(\mathrm{NO}_{3}\right)$ removal was obtained in both ex-situ and in-situ trials. Ammonia $\left(\mathrm{NH}_{3}\right)$ concentration was drastically reduced from 3.5 to 0.00 $\mathrm{mg} \mathrm{L}^{-1}(100 \%)$ in ex-situ and in-situ treatment. In general, the total amount of minerals was remarkably reduced in the treated polluted water.

Cheah et al. (2018) reported that the total hardness (due to $\mathrm{Na}, \mathrm{K}, \mathrm{Ca}$, etc.) was reduced drastically (69\%) when the sewage water was treated with Scenedesmus sp. Pham and Bui (2020) reported that the algal-based remediation of river water found a reduction in calcium (67.1\%) and potassium (67.4\%) contents from polluted river water in a short duration of the treatment process. The sulfate content of treated effluent with Scenedesmus sp. was reduced to

43.9\%. Similarly, Liang et al. (2013) reported the reduction of Sulfate in the sewage effluent by microalga Chlorella sp. Lee et al. (2013), reported that the alkalinity of effluent was reduced to $44 \%$ by Scenedesmus dimorphus and noted high alkalinity, which harms aquatic organisms.

In-situ phycoremediation mainly focused on treating the polluted water in field-based waste stabilization ponds system has proven to be for treating polluted water in terms of the reduced physicochemical level parameters than ex-situ phycoremediation. Similarly, Whitton et al. (2016) studied aerobic, facultative, and anaerobic pond methods to remediate the polluted water by nutrient removal. The results indicate an efficient reduction of BOD, COD, and TSS. Live algae possess intracellular and extracellular polyphosphates that are involved in metal sequestration and metals binding process (Zhao et al. 2015). The cell wall of microalgae consists of several functional groups such as carboxyl, hydroxyl, phosphate, amino, and sulphydryl moieties from polysaccharides, proteins, and lipids molecules. Functional groups bestow a net negative charge to the cell surface and are reported to have an outstanding metal binding nature (Gupta and Rastogi, 2008).

\subsection{FTIR and SEM analysis of Scenedesmus sp.}

The FTIR analysis of microalgae is a real preference for tedious documentation of a functional group of dried microalgae (Xiong et al. 2016). In the present study, the FTIR spectra of control biomass (without treated) of Scenedesmus sp., and the polluted river water ex-situ and in-situ treated biomass are shown in Figure 8a, b, \& c respectively, and the characteristic functional groups were presented in Table 2 . The prominent region between the $3200 \mathrm{~cm}^{-1}-3600 \mathrm{~cm}^{-1}$ 
represented the stretching vibration of $-\mathrm{OH}$ groups. The peak value at $3311.42 \mathrm{~cm}^{-1}$ was shown the $-\mathrm{OH}$ groups stretching vibration. The intensive peaks between $2800 \mathrm{~cm}^{-1}-3000 \mathrm{~cm}^{-1}$ showed the presence of alkanes $(\mathrm{CH})$ groups. The untreated biomass indicated the curve at $2922 \mathrm{~cm}^{-1}$ of $\mathrm{C}-\mathrm{H}$ unequal vibration of aliphatic $\left(\mathrm{CH}_{2}\right)$ efficient clusters. The curve at $1655 \mathrm{~cm}^{-1}$ reflects a sharper due to the $\mathrm{C}=\mathrm{C}$ stretching of carbonyl clusters. The IR region between $1600-1585 \mathrm{~cm}^{-1}$ indicating the prominent peaks of C-C vibrational stretching of $1551 \mathrm{~cm}^{-1}$ aromatic clusters. $1100-1058 \mathrm{~cm}^{-1}$ were $\mathrm{P}=0$ or $\mathrm{C}-0$ stretching is maybe polysaccharides.

FTIR spectra of untreated biomass curves were expressed at $720 \mathrm{~cm}^{-1}$ show the occurrence of C-Cl stretching. The IR spectra of polluted water treated biomass represented an unstable of the peaks at $698 \mathrm{~cm}^{-1}$ and $690 \mathrm{~cm}^{-1}$. Similarly, Yu et al. (2019) reported the FTIR transmittance of dried biomass of Scenedesmus sp. as an aliphatic character at 400-800, phenols, and alcoholic groups at 1,000-1,400, carboxyl group at 1,500-1,700 $\mathrm{cm}^{-1}$, hydroxyl group: $3,200-3,400 \mathrm{~cm}^{-1}$. These chemical groups could act as an agent to absorb the pollutants present in the polluted environment (Xiong et al. 2016), and the spectrum of polluted effluent ( $\mathrm{Pb}, \mathrm{Cr}, \mathrm{Co}, \mathrm{Ni}$, and $\mathrm{Cu}$ ) treated biomass (in-situ and ex-situ) revealed broad peaks in frequency observed at 3,386 $\mathrm{cm}^{-1}$ and 3,380 $\mathrm{cm}^{-1}$, but these peaks were absent in control biomass. Few functional group changes were perceived in the spectra of treated biomass, which indicates that the - $\mathrm{OH}$ groups might be involved in the metal absorption mechanism of Scenedesmus sp. Similarly, Castrillo et al. (2013) stated that the Chlorella sp. treated with minerals has interacted with $\mathrm{COOH},-\mathrm{OH}$, and $\mathrm{C}=\mathrm{O}$ clusters that have absorbed the pollutants effectively from the polluted water.

The results of the SEM analysis of the present study showed that the untreated algal cells shown standard shape with a smooth, transparent external layer found in the outer cell surface (Fig. 9a). After treating the water, the cells become slightly rough and crenelated textures, and some elements were found on the surface of the cell wall (Fig. 9b and 9c). Chiu et al. (2015) explained that surface protuberance on the algal cell surface due to the deposition of crystallized salts absorbed from polluted water. The approximate size of the Scenedesmus sp. was recorded as 6.04 to $8.01 \mu \mathrm{m}$ (Magnification of $4000 \times$ ). Similarly, Gour et al. (2016) reported the size of Scenedesmus quadricauda and Scenedesmus dimorphus ranged from 6.21 to $8.3 \mu \mathrm{m}$ and 8.28 to $8.74 \mu \mathrm{m}$, respectively

\section{Conclusion}

Based on the macroscopic and microscopic study, the predominant native microalgae culture was identified as Scenedesmus sp. The physicochemical properties such as EC $\left(3110.00\right.$ micro mho cm$\left.{ }^{-1}\right)$, turbidity $\left(17.10 \mathrm{mg} \mathrm{L}^{-1}\right)$, total hardness $\left(812.00 \mathrm{mg} \mathrm{L}^{-1}\right)$, BOD $\left(230 \mathrm{mg} \mathrm{L}^{-1}\right)$, and COD $\left(352 \mathrm{mg} \mathrm{L}^{-1}\right)$ and some minerals such as $\mathrm{Ca}\left(232.00 \mathrm{mg} \mathrm{L}^{-1}\right)$, Sulfate $\left(532.00 \mathrm{mg} \mathrm{L}^{-1}\right)$ were not under the acceptable limits of Indian standards. Three sets of treatments (I, II, \& III) were performed with various percentages of the biomass of Scenedesmus sp. in ex-situ and in-situ conditions on polluted river water samples. The treatment III showed a better reduction in river water pollution load in 14 days of treatment in ex-situ and in-situ study. The FTIR and SEM analyses confirmed that the presence of active functional groups in biomass of Scenedesmus sp. and SEM image described the absorption of pollutants resulting from the changes in the morphology of Scenedesmus sp. under 4000x Magnification. The present study findings concluded that a significant reduction was found in most of the tested physicochemical and basic minerals in the treated polluted water using microalgae Scenedesmus sp. in the in-situ study than ex-situ approach. The cultivation of algae in polluted water could be offering duel benefits: 1. Environmental welfares with the fabrication of algal biomass as phycoremediation. 2 . Which serves as a raw material for the production of biofuel and provides a valuable solution for contaminated water with possible obtaining of valued added raw material for biofuel production.

\section{Declarations}

The authors declare the following consent

\section{Funding}

Not applicable

\section{Competing interests}

The authors declare that they have no competing interests.

\section{Ethics approval}

Not applicable

\section{Availability of data and materials}

The detailed methodology and analytical data of the present findings are available from the corresponding author on reasonable request.

\section{Code availability}

Not applicable

\section{Authors' contributions}

S.V., M.P., \& P.A. planned the outline of the research work, carried out the research. M.N. prepared the manuscript draft, R.S., S.K., and B.P. support the manuscript writing and editing. D.N., project supervisor and administrator. The authors have read and approved the final manuscript.

\section{Acknowledgments}


The authors acknowledged the DST-FIST (SR/FIST/LSI-673/2016) for strengthening the instrumentation facility of the Biotechnology Department of Periyar University, Salem, Tamil Nadu. We would like to thank the District Water Testing Facility (TWAD), Salem, India, and Central Instrumentation Facility, St. Joseph's College, Tiruchirappalli, India for FT-IR and SEM analysis of samples.

\section{References}

1. Ajayan, K.V., Selvaraju, M., Unnikannan, P., Sruthi, P., 2015. Phycoremediation of tannery polluted water using microalgae Scenedesmus species, Int. J. Phyto. 17, 907-916. https://doi.org/10.1080/15226514.2014.989313.

2. Anjos, M., Fernandes, B.D., Vicente, A.A., Teixeira, J.A., Dragone, G., 2013. Optimization of CO2 bio-mitigation by Chlorella vulgaris. Tech. $139,149-154$. https://doi.org/10.1016/j.biortech.2013.04.032.

3. Angelaalincy, M., Senthilkumar, N., Karpagam, R., Kumar, G.G., Ashokkumar, B., Varalakshmi, P., 2017. Enhanced extracellular polysaccharide production and self-sustainable electricity generation for PAMFCs by Scenedesmus SB1. ACS omega, 2(7), 3754-3765. https://doi.org/10.1021/acsomega.7b00326

4. , 2005. (American Public Health Association) Standard methods for the examination of water and polluted water, Washington.

5. Asselborn, V., Fernandez, C., Zalocar, Y., Parodi, E.R., 2015. Effects of chlorpyrifos on the growth and ultrastructure of green algae, Ankistrodesmus gracilis. Ecotoxicol. Environ. Saf. 120, 334-341. https://doi.org/10.1016/j.ecoenv.2015.06.015

6. Castrillo, M., Lucas-Salas, L.M., Rodrí guez-Gil, C., Martınez, D., 2013. High pH-induced flocculation-sedimentation and effect of supernatant reuse on growth rate and lipid productivity of Scenedesmus obliquus and Chlorella vulgaris. Biores. Tech. 128, 324-329.

https://doi.org/10.1016/j.biortech.2012.10.114

7. Cheah, W.Y., Show, P.L., Juan, J.C., Chang, J.S., Ling, T.C., 2018. Enhancing biomass and lipid productions of microalgae in palm oil mill effluent using carbon and nutrient supplementation, Energy Convers. Manag. 164, 188-197. https://doi.org/10.1016/j.enconman.2018.02.094.

8. Chiu, S.Y., Kao, C.Y., Chen, T.Y., Chang, Y.B., Kuo, C.M., Lin, C.S., 2015. Cultivation of microalgal Chlorella for biomass and lipid production using wastewater as nutrient resource. Biores. Tech. 184,179-189. https://doi.org/10.1016/j.biortech.2014.11.080

9. , 2009. (Central Pollution Control Board) Status of water supply and polluted water generation and treatment in Class-I cities and Class-II towns of India-a report by CPCB. http://www.indiawaterportal.org

10. Derakhshandeh, M., Tezcan Un, U., 2019. Optimization of microalgae Scenedesmus growth rate using a central composite design statistical approach. Biomass and Bioene. 122, 211-220. https://doi.org/10.1016/j.biombioe.2019.01.022

11. Gonçalves, A.L., Pires, J.C.M., Simoes, M., 2017. A review on the use of microalgal consortia for polluted water treatment, Algal Res. $24,403-415$. https://doi.org/10.1016/j.algal.2016.11.008.

12. Gour, R.S., Chawla, A., Singh, H., Chauhan, R.S., Kant, A., 2016. Characterization and screening of native Scenedesmus isolates suitable for biofuel feedstock, PLoS One. 11, 1-16. https://doi.org/10.1371/journal.pone.0155321.

13. Gupta, V.K., , 2008. Equilibrium and kinetic modelling of cadmium(II) biosorption by nonliving algal biomass Oedogonium sp. from aqueous phase, J. Hazard. Mater. 153, 759-766. https://doi.org/10.1016/j.jhazmat.2007.09.021.

14. Kumar, K.S., Dahms, H.U., Won, E.J., Lee, J.S., Shin, K.H., 2015. Microalgae A promising tool for heavy metals remediation. Ecotoxicol. Environ. Saf. 113, 329-352. https://doi.org/10.1016/j.ecoenv.2014.12.019

15. Lee, J., Cho, D.H., Ramanan, R., Kim, B.H., Oh, H.M., Kim, H.S., 2013. Microalgae-associated bacteria play a key role in the flocculation of Chlorella vulgaris Tech. 131, 195-201. https://doi.org/10.1016/j.biortech.2012.11.130

16. Leng, L., Wei, L., Xiong, Q., Xu, S., Li, W., Lv, S., Lu, Q., Wan, L., Wen, Z., Zhou, W., 2020. Use of microalgae based technology for the removal of antibiotics from wastewater: A review. Chemos. 238, 124680. https://doi.org/10.1016/j.chemosphere.2019.124680

17. Li, W., Shi, Y., Gao, L., Liu, J., Cai, Y., 2013. Occurrence and removal of antibiotics in a municipal wastewater reclamation plant in Beijing, China. Chemos. 92, 435-444. https://doi.org/10.1016/j.chemosphere.2013.01.040

18. Liang, Z., Liu, Y., Ge, F., Xu, Y., Tao, N., Peng, F., Wong, M., 2013. Efficiency assessment and pH effect in removing nitrogen and phosphorus by algaebacteria combined system of Chlorella vulgaris and Bacillus lichenif Chemos. 92(10), 1383-1389. https://doi.org/10.1016/j.chemosphere.2013.05.014

19. Liu, X., Wang, K., Zhang, J., Wang, J., Wu, J., Peng, F., 2019. Ammonium removal potential and its conversion pathways by free and immobilized Scenedesmus obliquus from polluted water. Tech. 283, 184-190. https://doi.org/10.1016/j.biortech.2019.03.038.

20. Liu, J., Ge, Y., Cheng, H., Wu, L., Tian, G., 2013. Aerated swine lagoon wastewater: a promising alternative medium for Botryococcus braunii cultivation in open system. Biores. Tech. 139, 190-194. https://doi.org/10.1016/j.biortech.2013.04.036

21. Mata, TM., Melo, AC., Simoes, M., Caetano, NS., 2012. Parametric study of a brewery effluent treatment by microalgae Scenedesmus obliquus. Biores. Tech. 107, 151-158. https://doi.org/10.1016/j.biortech.2011.12.109

22. Mehrabadi, A., Craggs, R., Farid, M.M., 2015. Wastewater treatment high rate algal ponds (WWT HRAP) for low-cost biofuel production. Biores. Tech. 184, 202-214. https://doi.org/10.1016/j.biortech.2014.11.004

23. Mencio, A., Mas-Pla, J., Otero, N., Regas, O., Boy-Roura, M., Puig, R., Bach, J., Domènech, C., Zamorano, M.,Brusi, D., Folch, A., Nitrate pollution of groundwater; all right..., but nothing else?. Sci. Total Environ. 539, 241-251. https://doi.org/10.1016/j.scitotenv.2015.08.151

24. Murty, M.N., 2011. Policy Responses to Ecosystem Conservation in Hindukush Region Discussion Paper Ecosystem Services and Poverty Alleviation Study in South Asia (ESPASSA) A Situation Analysis for India and the Hindu-kush Himalayan Region, (2011). Annex 3.TERI. New Delhi

25. , 2019. The national green tribunal principal bench, New Delhi, India (2019). http://www.thehindu.com/sci-tech/energy-and-environment/india-ranked-no1-in-pollution-related-deaths-report/article19887858.ece 
26. Norvill, Z.N., Shilton, A., Guieysse, B., 2016. Emerging contaminant degradation and removal in algal wastewater treatment ponds: Identifying the research gaps. J. Hazard. Mater. 313, 291-309. https://doi: 10.1016/j.jhazmat.2016.03.085.

27. Posadas, E., Serejo, M.L., Blanco, S., Perez, R., García-Encina, P.A., Munoz, R., 2015. Minimization of biomethane oxygen concentration during biogas upgrading in algal-bacterial photo bioreactors. Algal Res. 12, 221-229. https://doi.org/10.1016/j.algal.2015.09.002

28. Rahman, M.A., Hasegawa, H., 2011. Aquatic arsenic: phytoremediation using floating macrophytes. Chemos. 83(5), 633-646. https://doi.org/10.1016/j.chemosphere.2011.02.045

29. Sarayu, K., Sandhya, S., 2012. Current technologies for biological treatment of textile polluted water-A review. Appl. Biochem. Biotechnol. 167, $645-661$. https://doi.org/10.1007/s12010-012-9716-6.

30. Suresh Kumar, K., Dahms, H.U., Won, E.J., Lee, J.S., Shin, K.H., 2015. Microalgae-A promising tool for heavy metal remediation. Ecotoxicol. Environ. Saf. 113, 329-352. https://doi.org/10.1016/j.ecoenv.2014.12.019

31. Sutherland, D.L., Ralph, P.J., 2019. Microalgal bioremediation of emerging contaminants-Opportunities and challenges. Water Res. 164. https://doi.org/10.1016/j.watres.2019.114921

32. Tripathi, R., Gupta, A., Thakur, I.S., 2019. An integrated approach for phycoremediation of polluted water and sustainable biodiesel production by green microalgae, Scenedesmus ISTGA1, Renew. Energy. 135, 617-625. https://doi.org/10.1016/j.renene.2018.12.056.

33. Tang, C.C., Tian, Y., Liang, H., Zuo, W., Wang, Z.W., Zhang, J., He, Z.W., 2018. Enhanced nitrogen and phosphorus removal from domestic polluted water via algae-assisted sequencing batch biofilm reactor. Tech. 250, 185-190. https://doi.org/10.1016/j.biortech.2017.11.028.

34. Verma, K., Kiran, P., Kumar, S., Vijaya Krishna., Himabindu, V., 2020. Phycoremediation of sewage-contaminated Lake Water using microalgae-bacteria coculture. Water Air Soil Pollut. 231, 299 https://doi.org/10.1007/s11270-020-04652-5.

35. Verma, K., Kumar, P.K., Krishna, S.V., Himabindu, 2020. Phycoremediation of sewage-contaminated lake water using microalgae-bacteria co-culture. Water Air Soil Pollut. 231, 299. https://doi.org/10.1007/s11270-020-04652-5.

36. Wan, J., Gu, J., Zhao, Q., Liu, Y., 2016. COD capture: a feasible option towards energy self-sufficient domestic wastewater treatment. Sci. Rep. 6, 25054. https://doi:10.1038/srep25054.

37. Wang, J., Zhou, W., Yang, H., Wang, F., Ruan, R., 2015. Trophic mode conversion and nitrogen deprivation of microalgae for high ammonium removal from synthetic polluted water. Tech. 196, 668-676. https://doi.org/10.1016/j.biortech.2015.08.036.

38. Wang, Y., Ho, S.H., Cheng, C.L., Guo, W.Q., Nagarajan, D., Ren, N.Q, Lee, D.J., Chang, J.S., 2016. Perspectives on the feasibility of using microalgae for industrial wastewater treatment. Biores. Tech. 222, 485-497. https://doi.org/10.1016/j.biortech.2016.09.106.

39. Whitton, R., Le Mevel, A., Pidou, M., Ometto, F., Villa, R., Jefferson, B., 2016. Influence of microalgal N and P com-position on wastewater nutrient remediation. Water Res. 91,371-378. https://doi.org/10.1016/j.watres.2015.12.054.

40. Xiong, J.Q., Kurade, M.B., Abou-Shanab, R.A.I., Ji, M.K., Choi, J., Kim, J.O., Jeon, B.H., 2016. Biodegradation of carbamazepine using freshwater microalgae Chlamydomonas Mexicana and Scenedesmus obliquus and the determination of its metabolic fate. Biores. Tech. 205, 183-190.

https://doi.org/10.1016/j.biortech.2016.01.038.

41. Yang, I.S., Salama, E.S., Kim, J.O., Govindwar, S.P., Kurade, M.B., Lee, M., Roh, H.S., Jeon, B.H., 2016. Cultivation and harvesting of microalgae in photobioreactor for biodiesel production and simultaneous nutrient removal, Energy Convers. Manag. 117, 54-62.

https://doi.org/10.1016/j.enconman.2016.03.017.

42. Yu, H., Kim, J., Lee, C., 2019. Nutrient removal and microalgal biomass production from different anaerobic digestion effluents with Chlorella Sci. Rep. 9(1), 6123. https://doi.org/10.1038/s41598-019-42521-2

43. Zhao, Y., Sun, S., Hu, C., Zhang, H., Xu, J., Ping, L., 2015. Performance of three microalgal strains in biogas slurry purification and biogas upgrade in response to various mixed light-emitting diode light wavelengths. Biores. Tech. 187, 338-345. https://doi.org/10.1016/j.biortech.2015.03.130.

\section{Tables}

\section{Table 1: Physicochemical properties of ex-situ and in-situ treated polluted water samples}




\begin{tabular}{|c|c|c|c|c|c|c|c|c|c|c|}
\hline \multirow{3}{*}{$\begin{array}{l}\text { Physicochemical } \\
\text { parameters } \\
\left(\mathrm{mg} \mathrm{L}^{-1}\right)\end{array}$} & \multirow{2}{*}{\multicolumn{3}{|c|}{$\begin{array}{l}\text { Indian standards } \\
\text { permissible limits } \\
\left(\mathrm{mg} \mathrm{L}^{-1}\right)\end{array}$}} & \multirow[t]{3}{*}{ Pre-Treated } & \multicolumn{6}{|c|}{ Post-Treated water } \\
\hline & & & & & \multicolumn{3}{|l|}{ In-vitro } & \multicolumn{3}{|l|}{ In-situ } \\
\hline & СРСВ & ICMR & ISI & & $\mathrm{TI}$ & TII & TII & $\mathrm{TI}$ & TII & TII \\
\hline Odor & - & - & - & Odor & Odorless & Odorless & Odorless & Odorless & Odorless & Odorless \\
\hline Turbidity (mg/L) & 10 & 25 & 10 & $17.10 \pm .03$ & $13.00 \pm .1$ & $9.10 \pm .2$ & $4.00 \pm .2$ & $13.10 \pm$. & $2.00 \pm$. & $2.00 \pm$. \\
\hline EC & 2000 & - & - & $3110.00 \pm 3.1$ & $2950.00 \pm 3.6$ & $2504.00 \pm 2.9$ & $2100.00 \pm 3.2$ & $2961.00 \pm 2.4$ & $2308.00 \pm 3.8$ & $2110.00 \pm 2.5$ \\
\hline $\mathrm{pH}$ & $\begin{array}{l}6.5- \\
8.5\end{array}$ & $\begin{array}{l}6.5- \\
9.2\end{array}$ & $\begin{array}{l}6.5- \\
8.5\end{array}$ & $6.99 \pm .2$ & $7.18 \pm .1$ & $7.54 \pm .3$ & $7.98 \pm .3$ & $7.44 \pm .2$ & $7.89 \pm .3$ & $8.44 \pm .2$ \\
\hline TDS (mg/L) & - & - & - & $2177.00 \pm 4.3$ & $1941.00 \pm 3.8$ & $1817.00 \pm 2.7$ & $1477.00 \pm 2.4$ & $1924.20 \pm 2.6$ & $1629.00 \pm 3.5$ & $1470.00 \pm 3.1$ \\
\hline Total alkalinity & 600 & - & - & $432.00 \pm 1.1$ & $408.00 \pm 2.1$ & $312.00 \pm 2.5$ & $288.00 \pm 2.4$ & $401.00 \pm 2.4$ & $327.00 \pm 1.9$ & $272.00 \pm 3.2$ \\
\hline Total hardness & 600 & 600 & 300 & $812.00 \pm 2.4$ & $734.00 \pm 3.6$ & $617.00 \pm 3.7$ & $328.00 \pm 4.1$ & $523.00 \pm 3.6$ & $409.00 \pm 4.2$ & $316.00 \pm 4.2$ \\
\hline BOD & 30 & - & - & $230.00 \pm 1.9$ & $221.00 \pm 2.5$ & $218.00 \pm 1.6$ & $205.00 \pm 2.8$ & $206.00 \pm 1.9$ & $184.00 \pm 3.1$ & $166.00 \pm 2.6$ \\
\hline COD & 250 & - & - & $352.00 \pm 2.8$ & $345.00 \pm 3.1$ & $323.00 \pm 2.6$ & $310.00 \pm 3.8$ & $308.00 \pm 2.7$ & $289.00 \pm 2.1$ & $270.00 \pm 3.6$ \\
\hline DO & & & & $1.65 \pm .41$ & $1.86 \pm .22$ & $2.28 \pm .75$ & $2.86 \pm .82$ & $2.11 \pm .47$ & $2.71 \pm .61$ & $3.80 \pm .83$ \\
\hline Free ammonia & - & - & - & $3.50 \pm .53$ & 0.00 & 0.00 & 0.00 & 0.00 & 0.00 & 0.00 \\
\hline Nitrite & - & - & - & $1.20 \pm .64$ & 0.00 & 0.00 & 0.00 & 0.00 & 0.00 & 0.00 \\
\hline Calcium & 200 & 200 & 75 & $232.00 \pm 3.4$ & $219.00 \pm 2.6$ & $126.00 \pm 1.7$ & $69.00 \pm .8$ & $187.00 \pm 1.9$ & $118.00 \pm 1.6$ & $67.00 \pm 1.2$ \\
\hline Magnesium & 100 & - & 30 & $56.00 \pm .89$ & $51.00 \pm .53$ & $48.00 \pm .42$ & $37.00 \pm .78$ & $51.00 \pm .34$ & $48.00 \pm .35$ & $36.00 \pm .75$ \\
\hline Sodium & - & - & - & $320.00 \pm 2.6$ & $308.00 \pm 4.1$ & $291.00 \pm 2.5$ & $260.00 \pm 3.2$ & $301.00 \pm 4.1$ & $279.00 \pm 2.4$ & $260.00 \pm 2.3$ \\
\hline Iron & 1.0 & 1.0 & 0.3 & $0.90 \pm .0$ & $0.71 \pm .01$ & $0.54 \pm .0$ & $0.10 \pm .0$ & $0.64 \pm .0$ & $0.48 \pm .0$ & $0.10 \pm .0$ \\
\hline Chloride & 1000 & 1000 & 250 & $420.00 \pm 4.2$ & $372.00 \pm 2.7$ & $301.00 \pm 3.1$ & $252.00 \pm 3.5$ & $403.00 \pm 2.8$ & $308.00 \pm 3.1$ & $248.00 \pm 3.7$ \\
\hline Sulfate & 400 & 400 & 150 & $532.00 \pm 3.6$ & $502.00 \pm 2.4$ & $410.00 \pm 3.7$ & $300.00 \pm 2.9$ & $511.00 \pm 3.1$ & $401.00 \pm 2.8$ & $295.00 \pm 2.7$ \\
\hline Phosphate & - & - & - & $2.90 \pm .80$ & $2.58 \pm .36$ & $2.29 \pm .27$ & $2.00 \pm .41$ & $2.51 \pm .18$ & $2.05 \pm .52$ & $1.50 \pm .11$ \\
\hline
\end{tabular}

Legend: The mentioned values are mean and standard error $( \pm)$ of triplicates. EC: Electric Conductivity, TDS: Total dissolved solids, BOD: Biological Oxygen Demand, COD: Chemical Oxygen Demand, DO: Dissolved Oxygen, CPCB: Central Pollution Control Board of India, ICMR: Indian Council of Medical Research of India, ISI: Indian Standards Institute of India.

Table 2: FT-IR analysis of Scenedesmus sp. biomass

\begin{tabular}{|c|c|c|c|c|c|c|c|c|c|}
\hline \multirow{2}{*}{$\begin{array}{l}\text { S. } \\
\text { No. }\end{array}$} & \multicolumn{3}{|l|}{ Control } & \multicolumn{3}{|l|}{ Ex-situ study } & \multicolumn{3}{|l|}{ In-situ study } \\
\hline & $\begin{array}{l}\text { Wavelength } \\
\left(\mathrm{cm}^{-1}\right)\end{array}$ & $\begin{array}{l}\text { Types of } \\
\text { Vibrations }\end{array}$ & $\begin{array}{l}\text { Functional } \\
\text { Groups }\end{array}$ & $\begin{array}{l}\text { Wavelength } \\
\left(\mathrm{cm}^{-1}\right)\end{array}$ & $\begin{array}{l}\text { Types of } \\
\text { Vibrations }\end{array}$ & $\begin{array}{l}\text { Functional } \\
\text { groups }\end{array}$ & $\begin{array}{l}\text { Wavelength } \\
\left(\mathrm{cm}^{-1}\right)\end{array}$ & $\begin{array}{l}\text { Types of } \\
\text { Vibrations }\end{array}$ & $\begin{array}{l}\text { Functional } \\
\text { groups }\end{array}$ \\
\hline 1. & 3311.42 & $\mathrm{O}-\mathrm{H}$ stretch & Alcohols & 3920.42 & O-H Stretch & Alcohols & 3920.47 & O-H Stretch & alcohols \\
\hline 2. & 2922.40 & C-H stretch & Alkanes & 2924.91 & C-H Stretch & Alkanes & 2926.87 & C-H Stretch & alkanes \\
\hline 3. & 2853.17 & $\begin{array}{l}\mathrm{CH}_{2} \text { symmetric } \\
\text { Phosphines }\end{array}$ & $\begin{array}{l}-\mathrm{CH}_{2} \text { in Aliphatic } \\
\text { compound }\end{array}$ & 2855.77 & $-\mathrm{CH}_{3}$ stretch & $\begin{array}{l}\text { Aliphatic } \\
\text { compound }\end{array}$ & 2861.31 & $\begin{array}{l}-\mathrm{CH}_{3} \\
\text { Stretch }\end{array}$ & $\begin{array}{l}\text { Aliphatic } \\
\text { compound }\end{array}$ \\
\hline 4. & 1655.96 & $-C=C$ stretch & Alkanes & 1651.19 & $-C=C$ stretch & Alkanes & 1652.88 & $-C=C$ stretch & Alkanes \\
\hline 5. & 1449.86 & $\mathrm{C}-\mathrm{H}$ bend & Alkanes & 1423.14 & $-\mathrm{C}=\mathrm{C}$ stretch & Aromatics & 1452.41 & $\begin{array}{l}\mathrm{N}-\mathrm{O} \\
\text { asymmetric }\end{array}$ & $\begin{array}{l}\text { Nitro } \\
\text { compound }\end{array}$ \\
\hline 6. & 720.21 & C-H rock & Alkanes & 698.98 & $\mathrm{C}-\mathrm{H}$ bend & Alkynes & 690.54 & $\mathrm{C}-\mathrm{H}$ bend & Alkynes \\
\hline
\end{tabular}

\section{Figures}




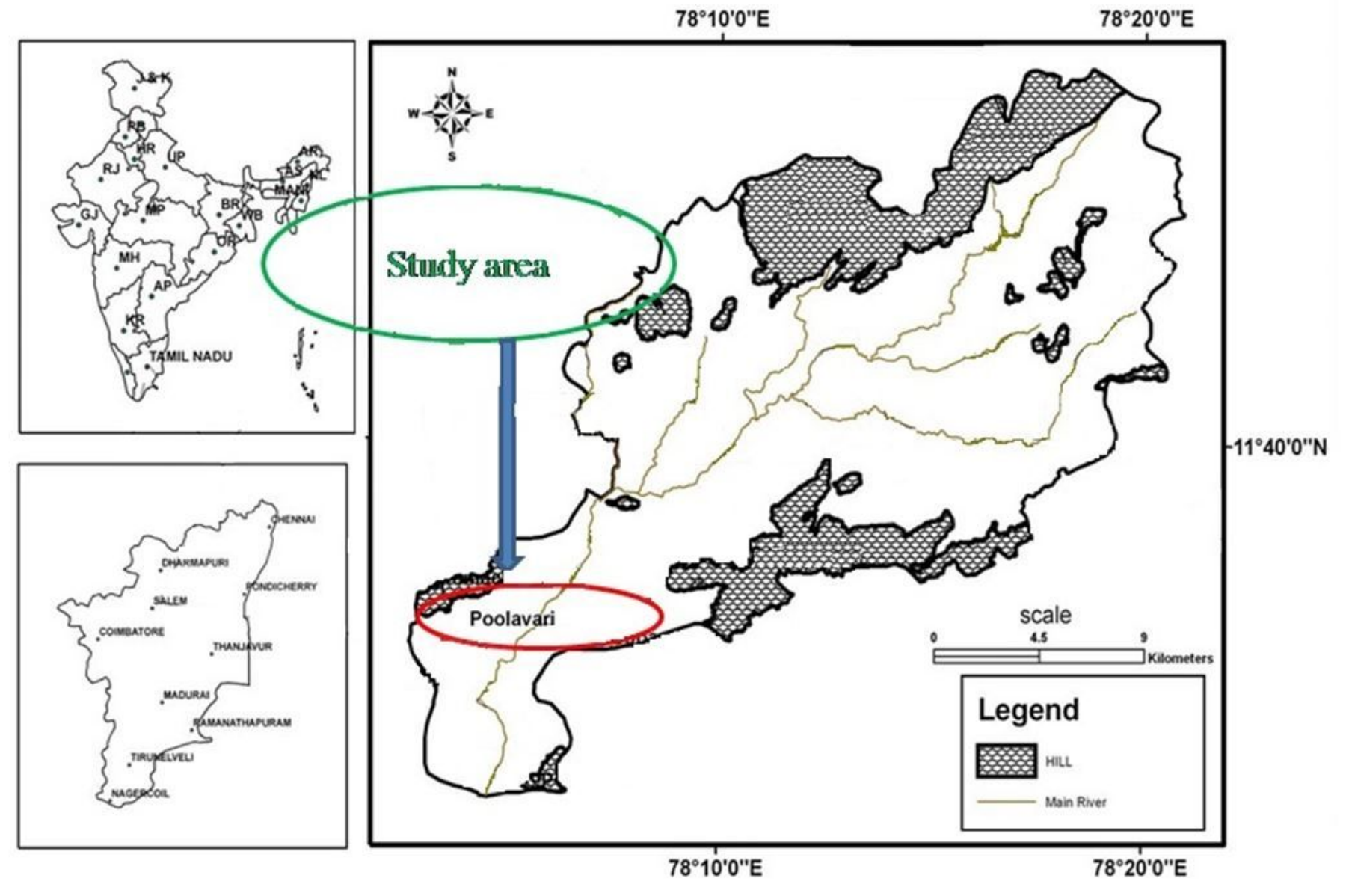

Figure 1

Study area for sample collection (encircled in red color)

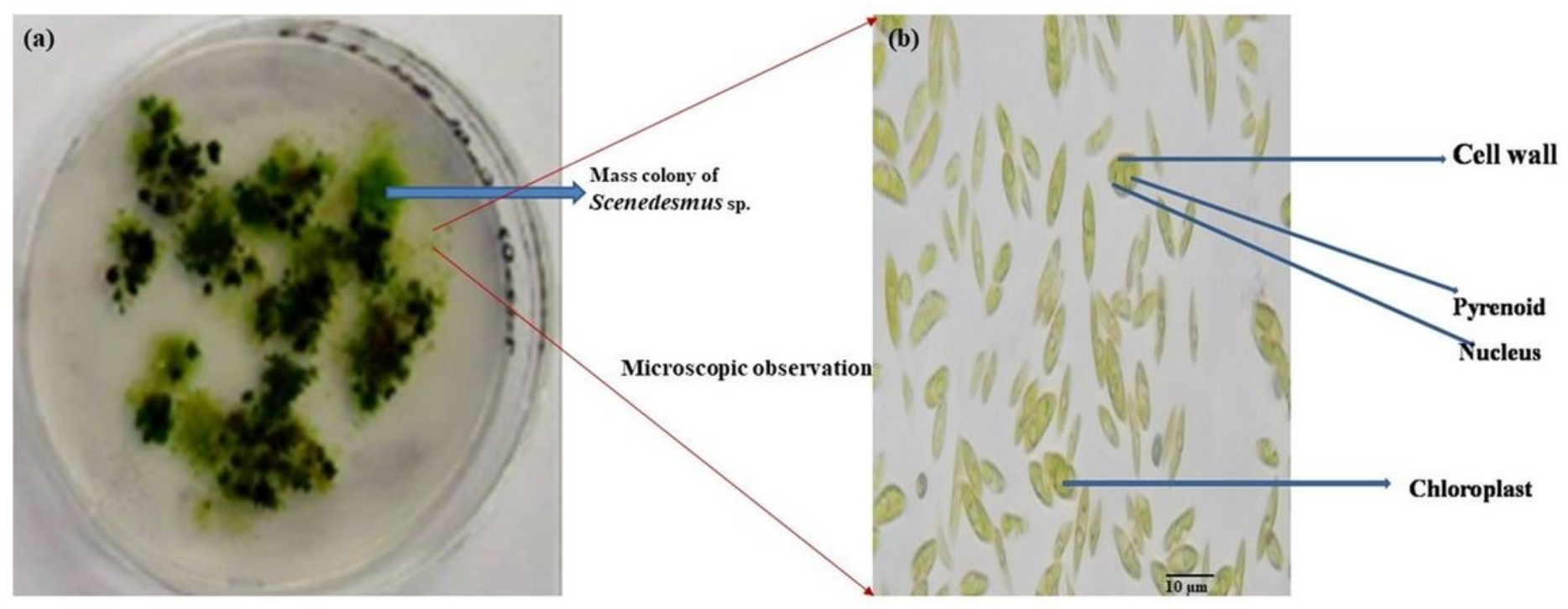

Figure 2

Macroscopic and microscopic observation of microalgae. (a) Colony morphology (b) microscopic view of Scenedesmus sp. 


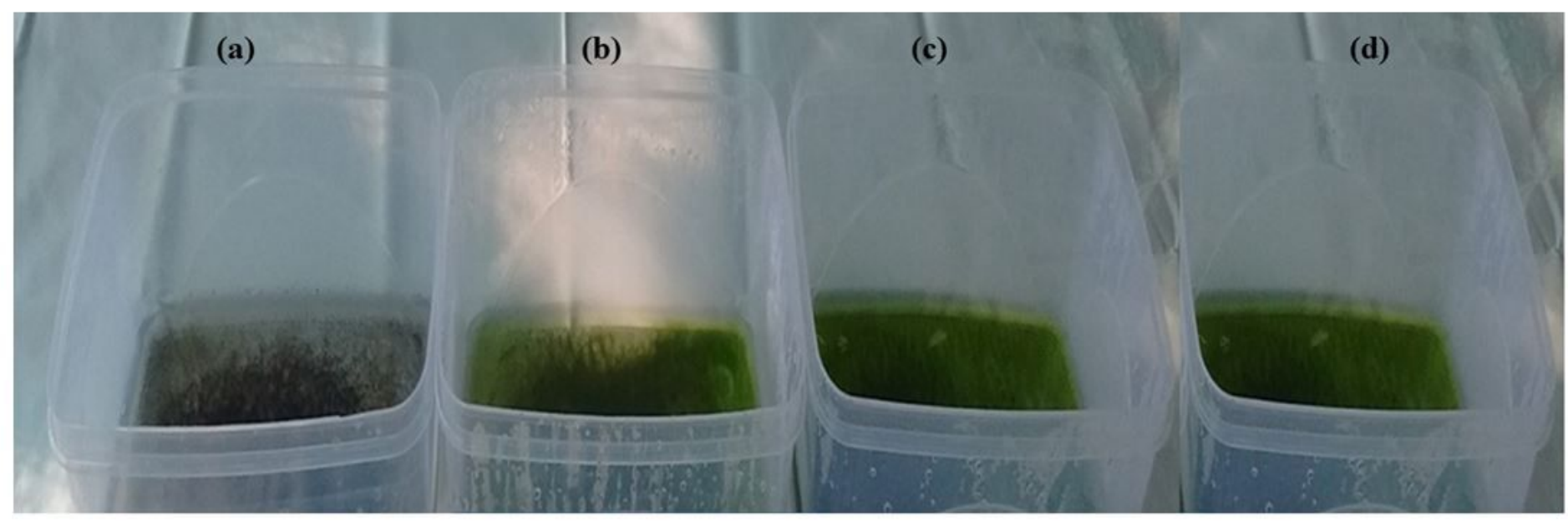

Figure 3

Phycoremediation of polluted water using Scenedesmus sp. in ex-situ study. (a) Control (b) Treatment I (c) Treatment II (d) Treatment III

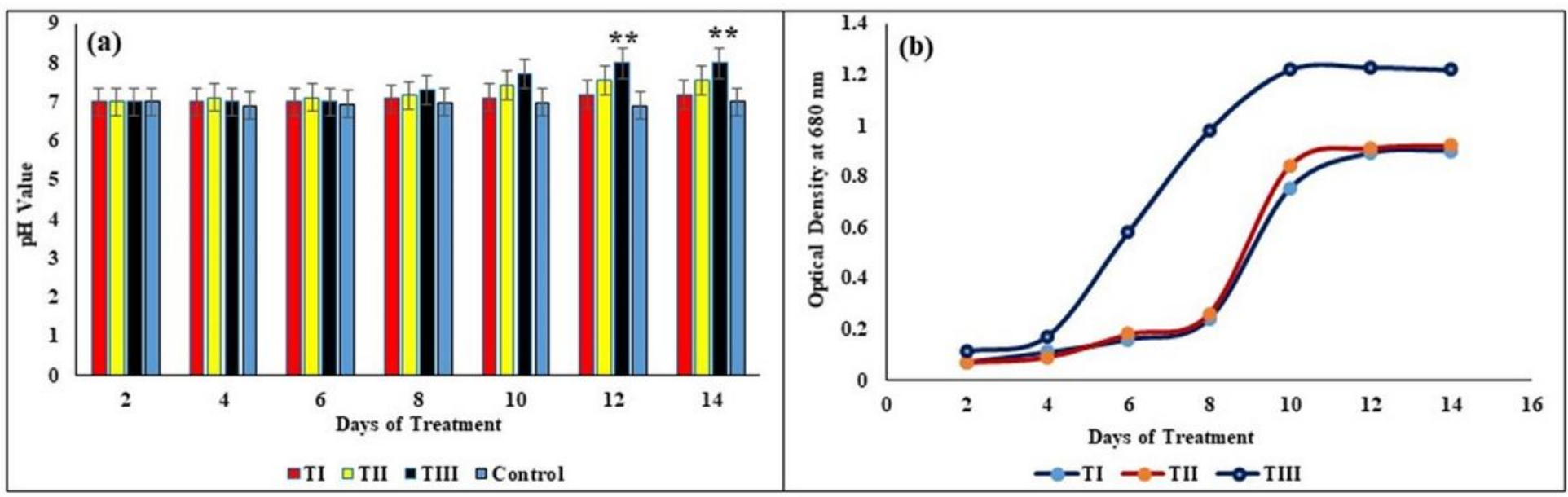

Figure 4

The mentioned values are mean and standard error $( \pm)$ of triplicates. **: Statistically significant at $\mathrm{P}<0.005$ (a) The changes in pH value of polluted water during the ex-situ treatment. (b) Growth kinetic of Scenedesmus sp. during the phycoremediation process on river water: ex-situ analysis

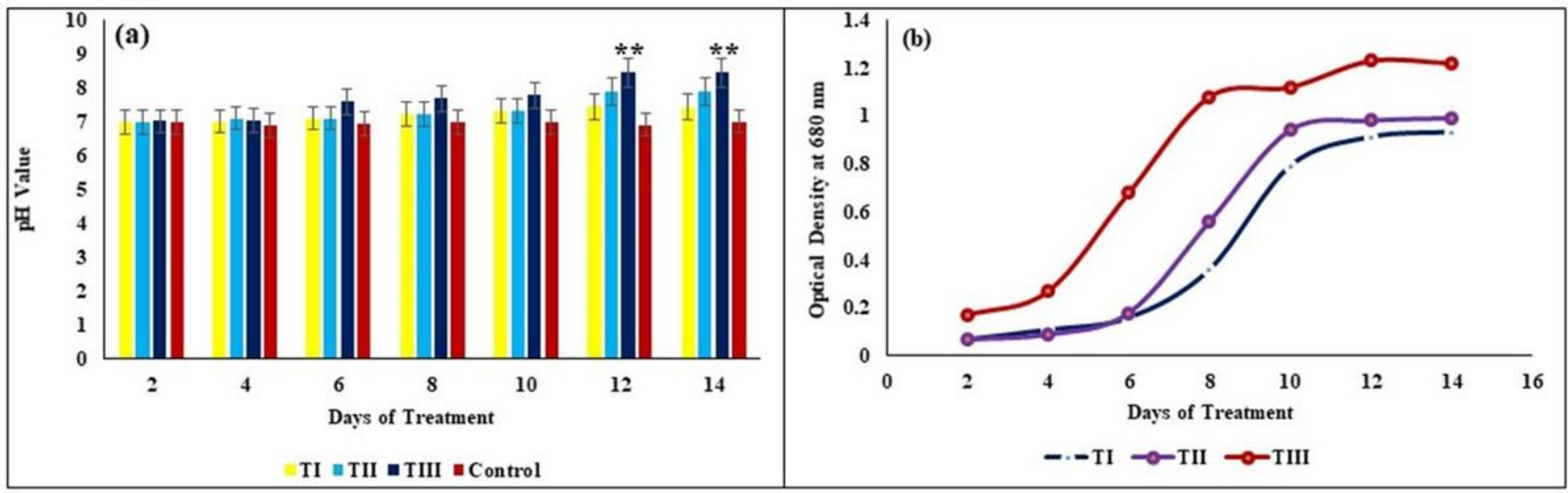

\section{Figure 5}

The mentioned values are mean and standard error $( \pm)$ of triplicates. ${ }^{*}$ : Statistically significant at $\mathrm{P}<0.005$ (a) The changes in pH value of polluted water during the in-situ treatment (stabilization pond system). (b) Growth kinetic of Scenedesmus sp. during the phycoremediation process on river water: in-situ analysis 


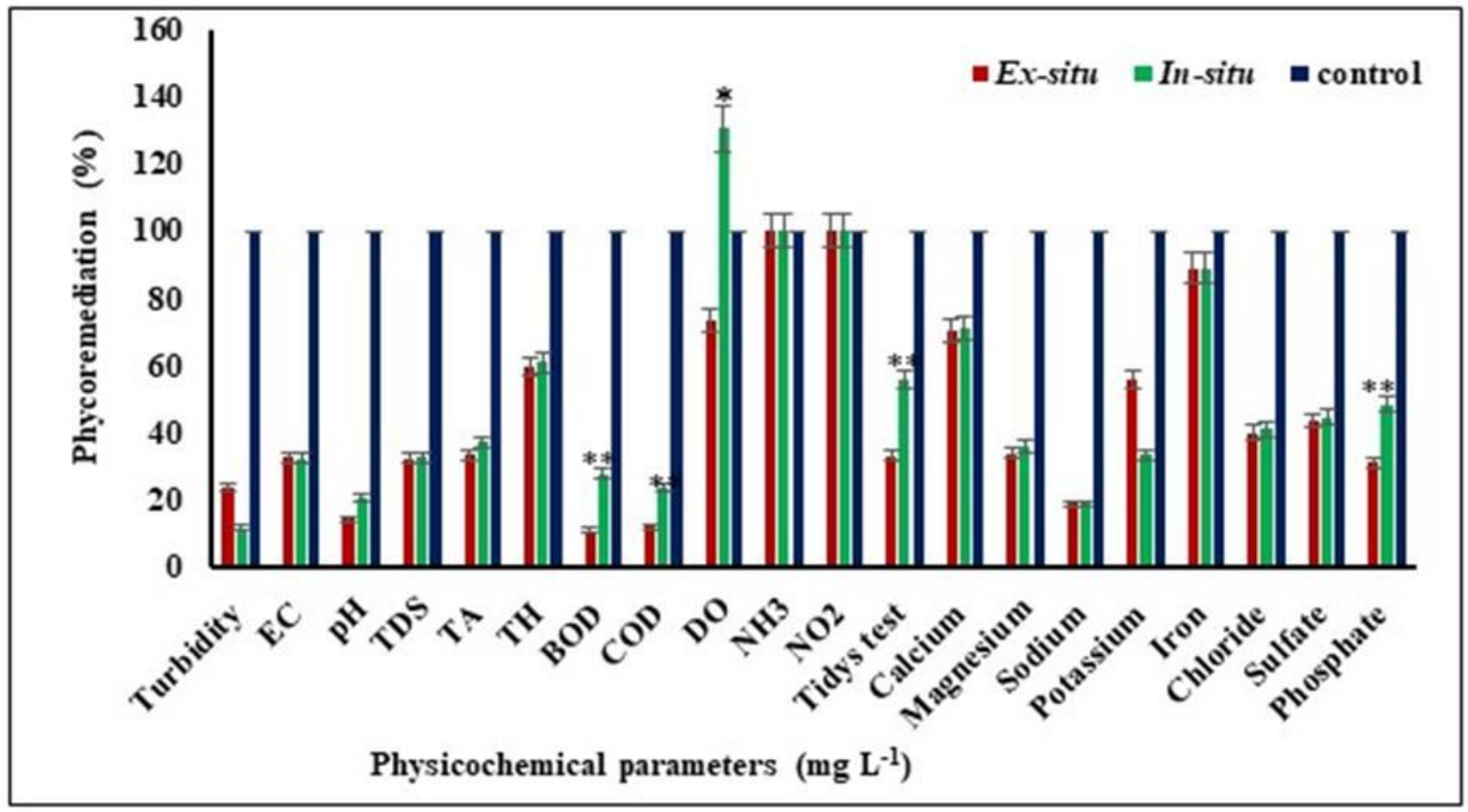

Figure 6

Percentage of phycoremediation in polluted river water by ex-situ and in-situ analysis compared with control. The mentioned values are mean and standard error ( \pm ) of triplicates. **: Statistically significant at $P<0.005$
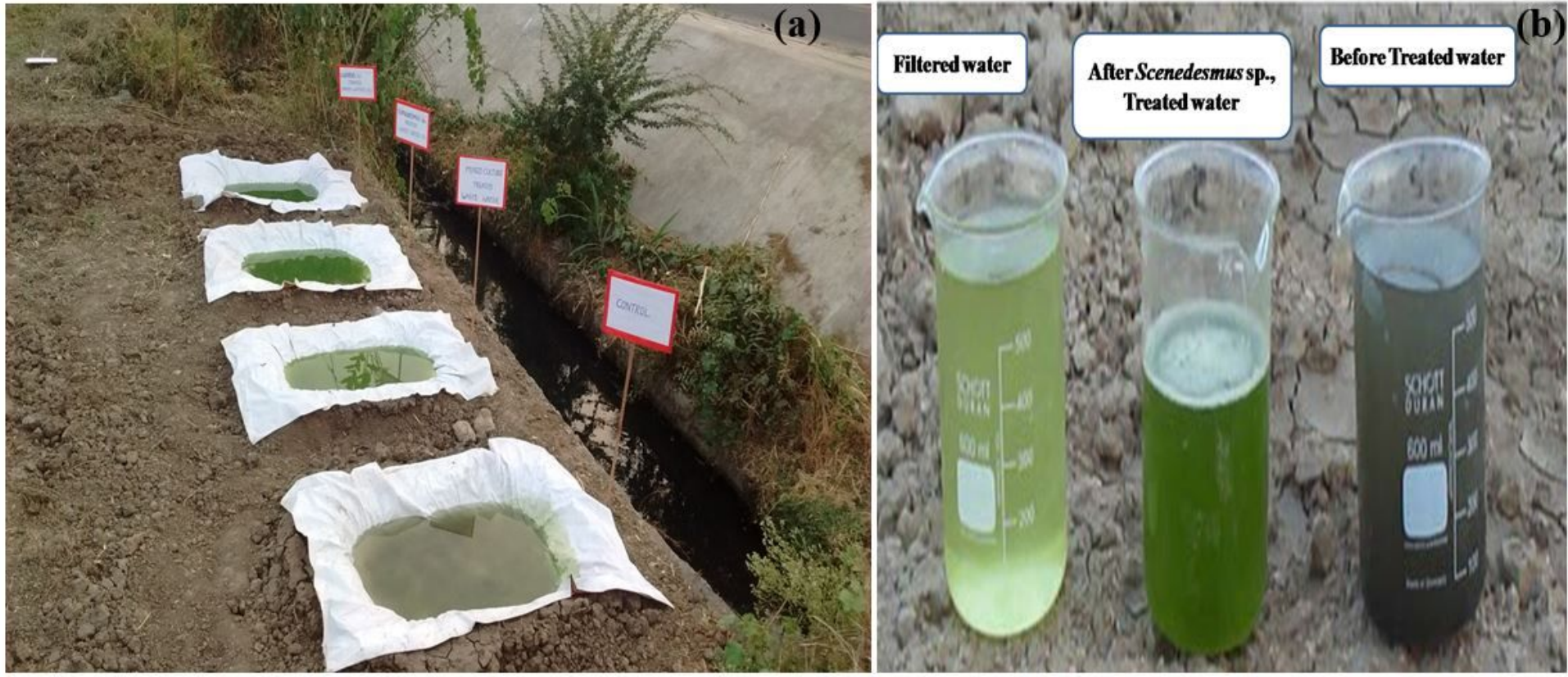

Figure 7

(a) In-situ phycoremediation experimental set up (waste stabilization pond system) (b) Pre and post treated water samples from the in-situ treatment 


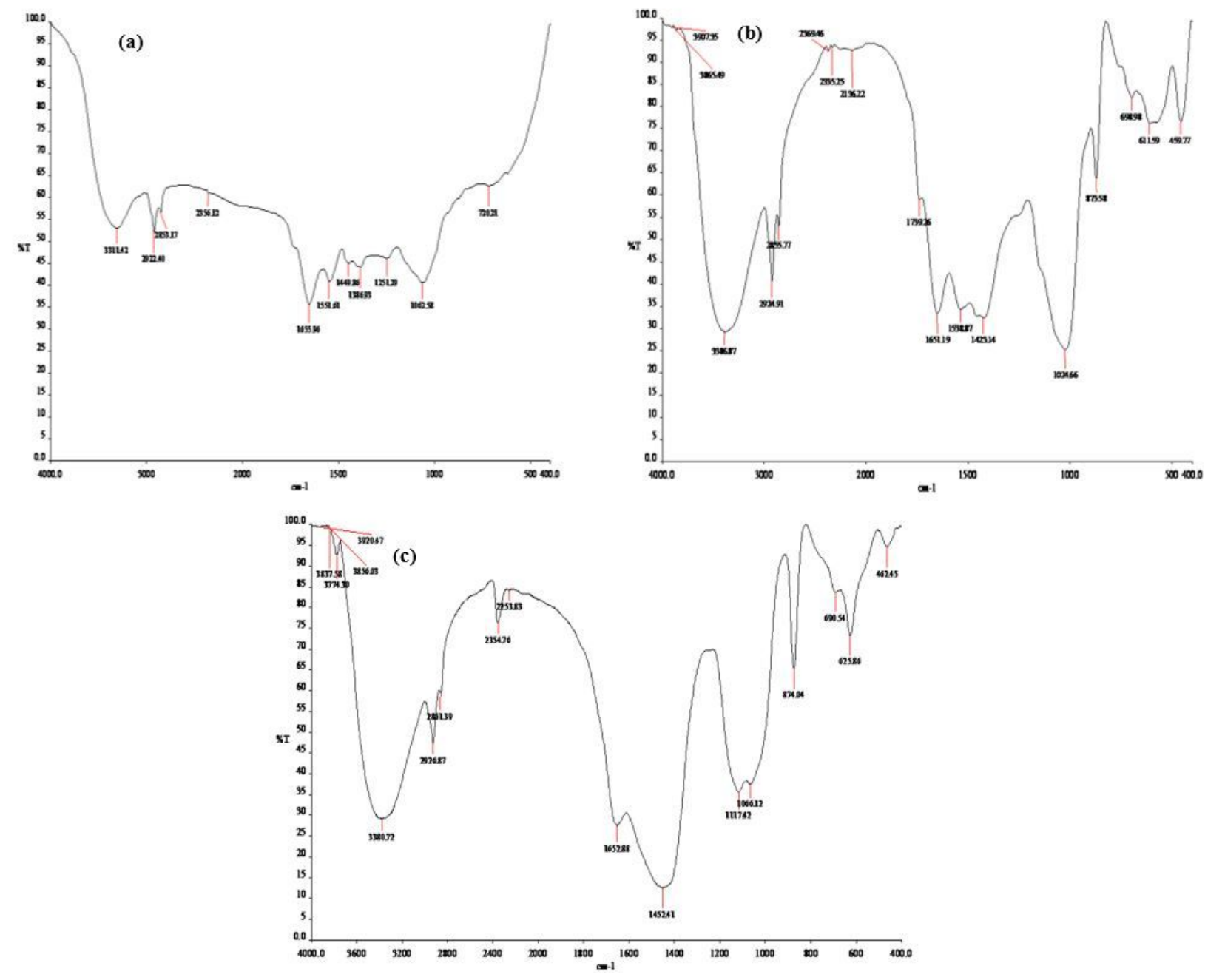

Figure 8

FTIR spectrum of Scenedesmus sp. biomass compared with control (a) control (b) ex-situ treatment (c) in-situ treatment 


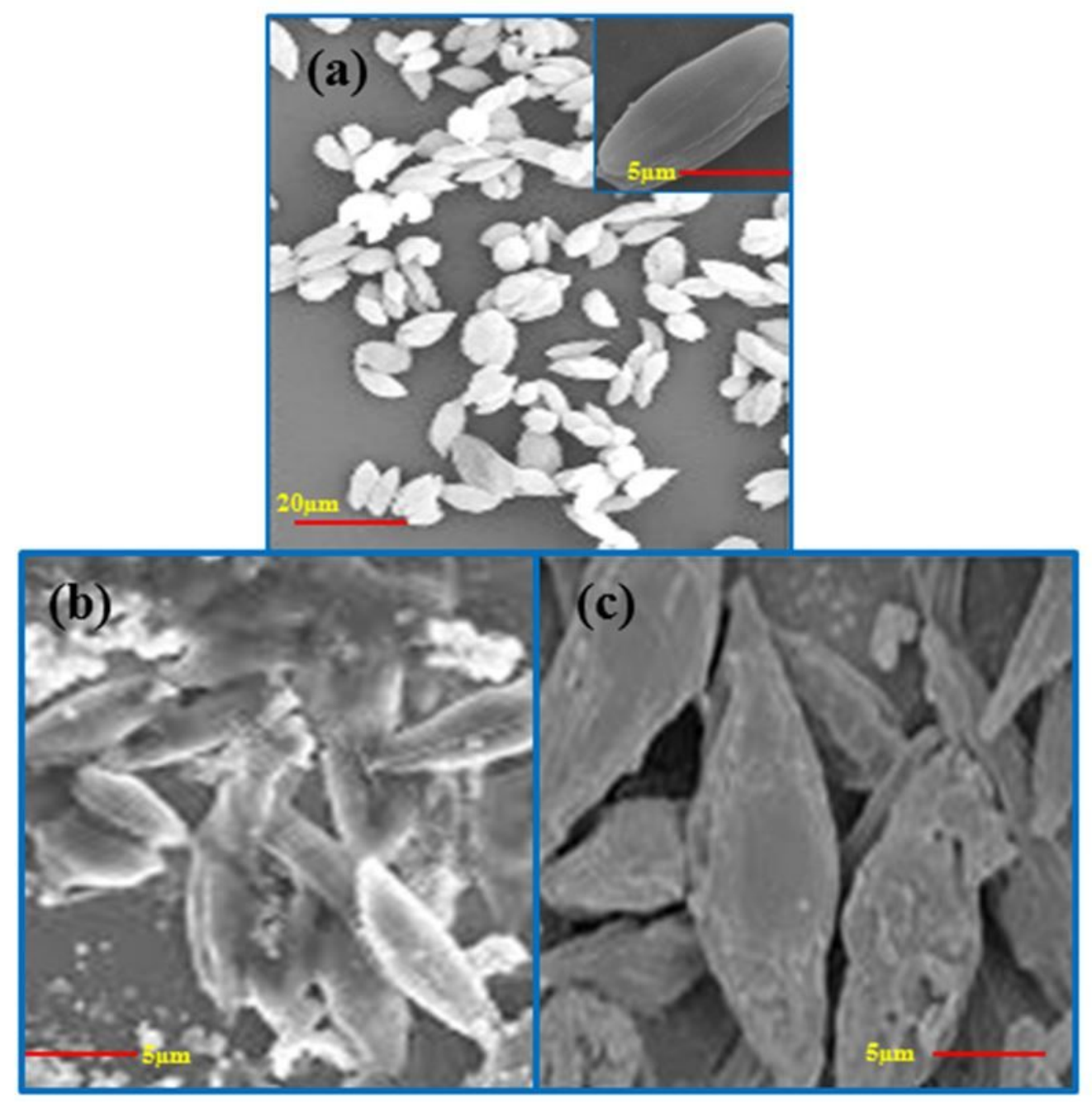

Figure 9

SEM analysis of treated Scenedesmus sp. morphology compared with control (a) Control biomass (b) ex-situ treated biomass (c) in-situ treated biomass 